Implementation of The Wavelet Transformation Algorithm for The Recognition and Recitation of The Qur'anic Verses Through Voice

\title{
IMPLEMENTATION OF THE WAVELET TRANSFORMATION ALGORITHM FOR THE RECOGNITION AND RECITATION OF THE QUR'ANIC VERSES THROUGH VOICE
}

\author{
Bustami, Sayed Fachrurrazi, Fahrul Rozi Siregar \\ Informatics, Malikussaleh University \\ frozi0608@gmail.com ${ }^{1}$
}

\begin{abstract}
Abstract- The advancement of computer technology not only makes it easy for humans to carry out activities. One of the human intelligences planted into computer technology is recognizing the Qur'anic verses in Surah Ar-Rahman. Wafelet transformation method is one method for sound recognition, this system recognizes the verses of Al-Qur'an Surah Ar-Rahman from recorded sound files with the .wav file extension and built using the Delphi programming language.
\end{abstract}

Keywords : technology, Al-Qur'an, Wavelet

\section{Introduction}

The Qur'an is an Islamic holy book that contains the word of God revealed to the Prophet Muhammad, with the intermediary of the angel Jibril to be read, understood and practiced as a guide or a guide to life for mankind (KBBI, 2008). The main purpose revealed by the Qur'an is to make human guidance in managing life in order to obtain happiness in the world and the hereafter described in the letter AL-Baqarah 2:2. Memorizing the Qur'an is one of the more rewarding noble activities in Islam. Ulama have explained many methods in memorizing the Qur'an. Memorizing the Qur'an is one of the most commendable activities in Islam, which, known to be able to act for the world and the hereafter. 
One letter is rewarded with 1 good and is added to 10 virtues. "Abdullah bin Mas'ud radhiyallahu 'anhu said:" The Prophet sallallaahu' alaihi wasallam said: "Whoever reads one letter from the Qur'an then for him one goodness with that reading, one goodness is included into 10 goodness and I do not say aliflammim one letter but Alif one letter, Laam one letter and Miim one letter. Everyone has the desire to memorize the Koran. However, not all of them want to memorize it. Even those who have memorized many seem like "like it or not". Memorizing activities sometimes form a lazy person, including lazy to repeat and less responsible for memorization. Memorizing the Koran is a package. When people memorize, then they automatically practice discipline, sincerity, patience, and mandate. Not just for khatam, but also for learning faithfully to live with the Koran. The real hafiz graduation is when humans are gathered in Mahsyar, not when in the world.[4]

\section{Basic Theory}

\subsection{Al-Qur'an}

In the language Al-Quran comes from Arabic, namely qaraa-yaqrauquraanan which means reading. That is explained by Al-Qur'an in Surah Al-Qiyamah verses 17-18. The meaning is actually on our responsibility to collect it (on your chest) and (make you smart) read it. When We have finished reading it Then follow the reading. (Surah AlQiyamaah 17-18).

In terms of terminology, according to Manna 'Al-Qhattan

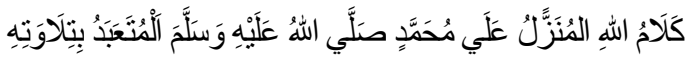

That means : "The Book of God revealed to the Prophet Muhammad, and those who read it receive merit".

\subsection{Ar-Rahman :}

Surah Ar-Rahman is the letter name in the 55th Al-Quran. This Surah begins with a verse which is a proof, a sign, and a manifestation. The first is the God of Mercy, who teaches the knowledge of himself through the Qur'an (al-Mizan). The first manifestation of God is His light, the 
light of knowledge. Unbelievers want to extinguish the light of Allah and His commands, but Allah does not allow it because "Allah is the light of heaven and earth".

\subsection{Sound Signal}

Audio is interpreted as sound or sound reproduction. Sound waves are waves produced from a vibrating object. The picture is the guitar string picked, the guitar will vibrate and this vibration propagates in the air, or water, or other material.[3] The only place where sound can't propagate is a vacuum. These sound waves have valleys and hills, one fruit and a hill will produce one cycle and period. This cycle continues and repeatedly brings the concept of frequency. Clearly, frequency is the number of cycles that occur in one second. The unit of frequency is Hertz or Hz.[2]

\subsection{Wavelet Transformation}

Wavelet transform is defined as small wave or short wave. The Wavelet transform will convert a signal into a series of Wavelets. The short wave is a basic function located at different times. Decomposition of Averages and Differences of Average Decomposition and Reduction (Differences) play an important role in understanding wavelet transformations.[1] Wavelet transformation is an improvement from Fourier transformation on Fourier can only determine the frequency that appears on a signal, but cannot determine when (where) that frequency appears. To understand this smoothing and subtraction decomposition, the following is given a 1-dimensional image example with dimension 8

\begin{tabular}{|l|l|l|l|l|l|l|l|}
\hline 37 & 35 & 28 & 28 & 58 & 18 & 21 & 15 \\
\hline
\end{tabular}

Leveling is done by calculating the average value of 2 pairs of data using the formula:

$$
p=\frac{x+y}{2}
$$

while the reduction is done by formula 


$$
p=\frac{x-y}{2}
$$

The results of the leveling process for the image above are :

While the $\frac{37 \quad 35}{36} \quad \frac{28 \quad 28}{28} \quad \frac{58 \quad 18}{38} \quad \frac{21 \quad 15}{18}$

$$
\begin{array}{lllll}
\frac{37}{1} \quad 35 & \frac{28}{0} \quad 28 & \frac{58 \quad 18}{20} & \frac{21 \quad 15}{3}
\end{array}
$$

So the results of the leveling decomposition process and the reduction of the image above are :

\begin{tabular}{|l|l|l|l|l|l|l|l|}
\hline 36 & 28 & 38 & 18 & 1 & 0 & 20 & 3 \\
\hline
\end{tabular}

3. Result and Discussion

\subsection{System Scheme}

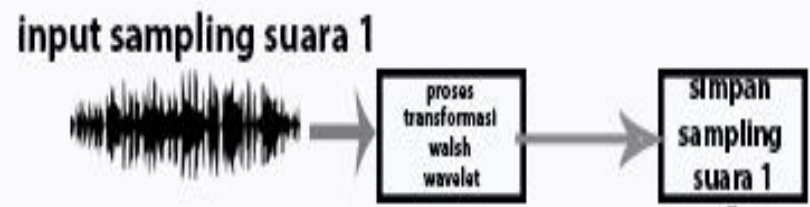

input sampling suara 2
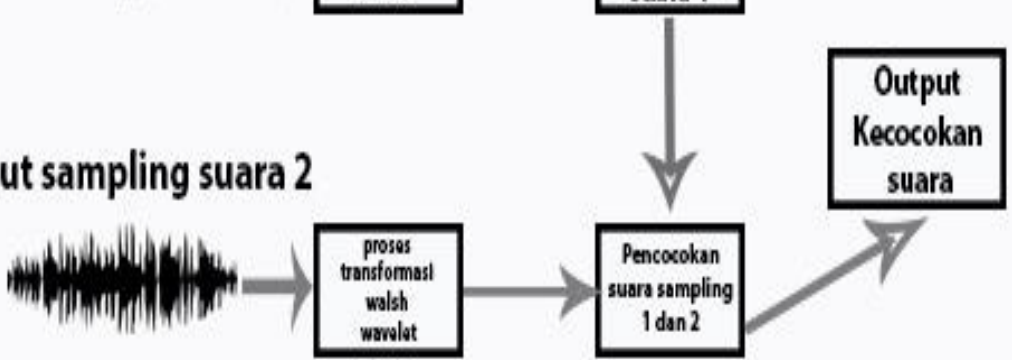


\subsection{System Scheme for Flowcharts}

The method scheme is a flowchat design that describes the process of applying the Wavelet Transformation formula to find out the results of systematic calculation values based on sound detection input.

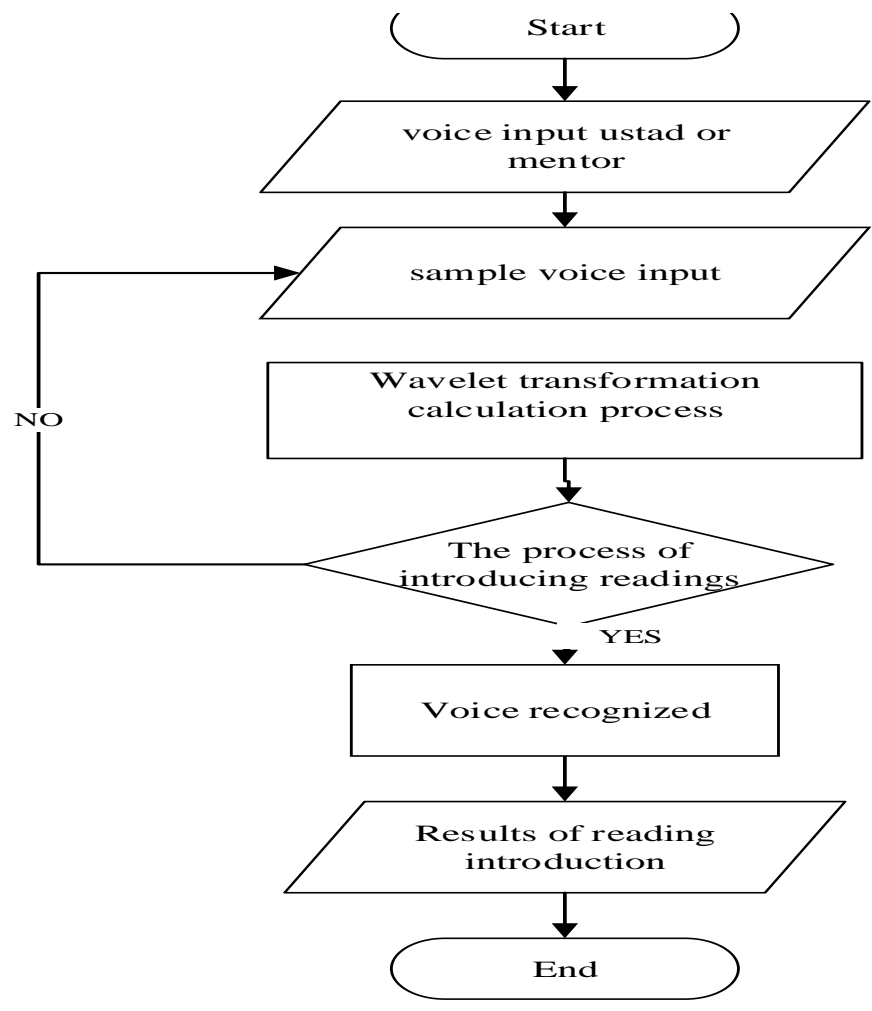

\subsection{Memory Test Form}

The Memory Test Form is used to conduct sound training and testing in real time with a case study of Surah Ar-Rahman. This menu consists of submenu for training sounds and surah Ar-Rahman reading test sounds which will be read in real time 


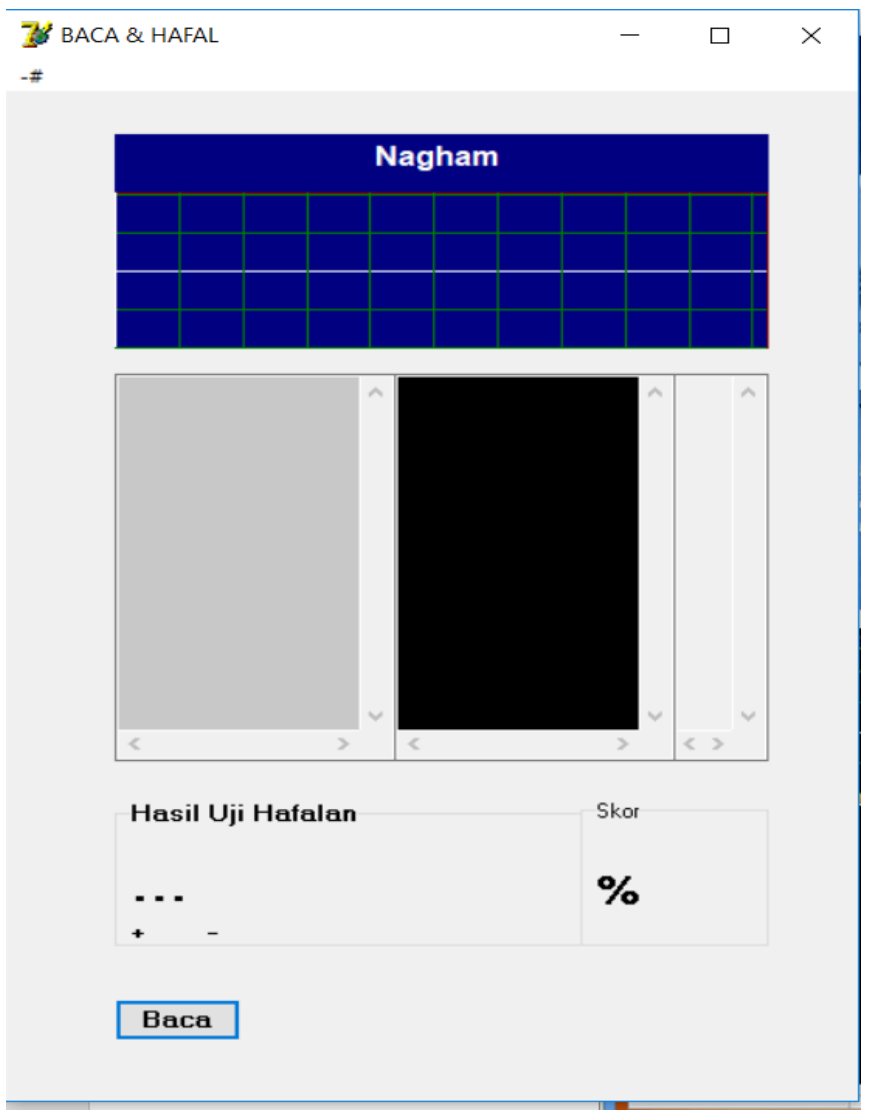

Picture 3.1 Form Detecion

\subsection{Voice Recognition Results}

Before conducting the test, the first step is to input the training sounds in real time, because the programs that have been designed are not database so the training process must also be in real time. The training itself is carried out to determine energy as a reference so that it can identify a characteristic of the voice of Sura Rahman.

While testing is done to compare the sound energy that is used as a reference with the sound energy in the previous reading, whether the energy can be recognized as a feature or not, but in this explanation I use 
the curd nagham (rhythm). The following is the display of the results of the reading memorization system in Surah Ar-Rahman.

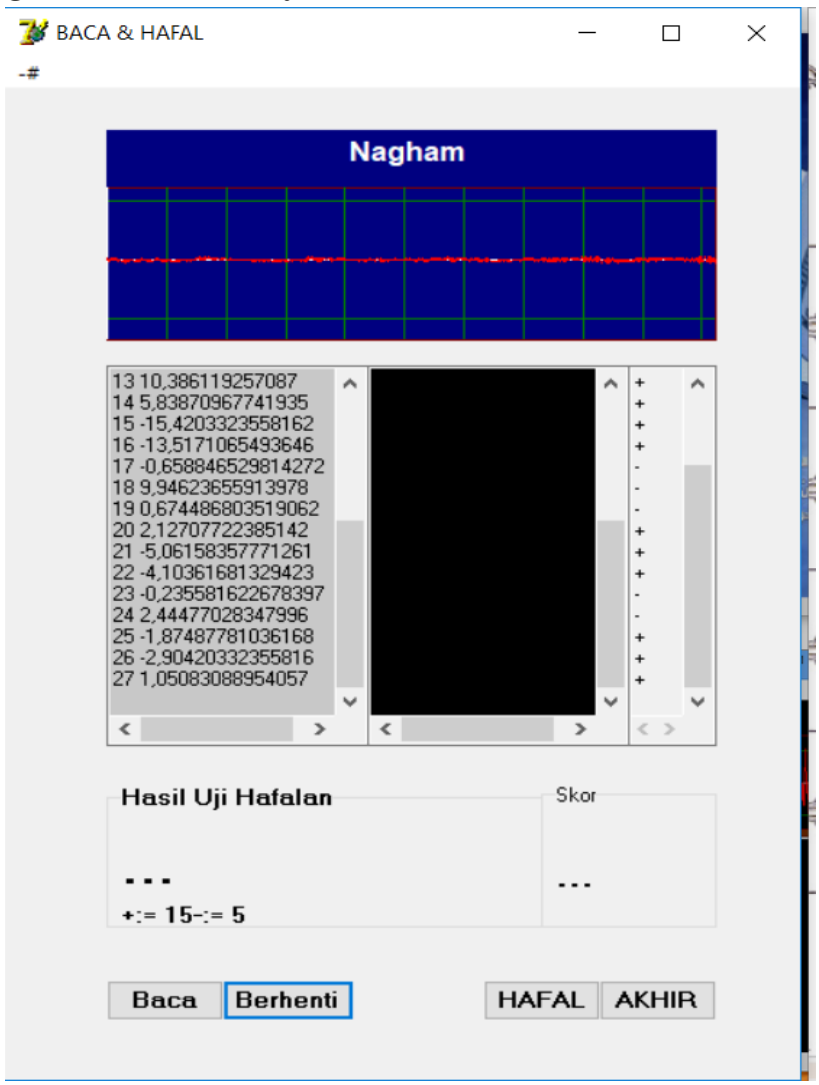

Picture 3.2 Input training sounds in real time

The picture above is an example of sample input sound in real time, the "Read" button is pressed to start entering the mentor's voice then press the "Stop" button. The two buttons must be pressed accordingly because if it is not pressed the voice input process will fail. 


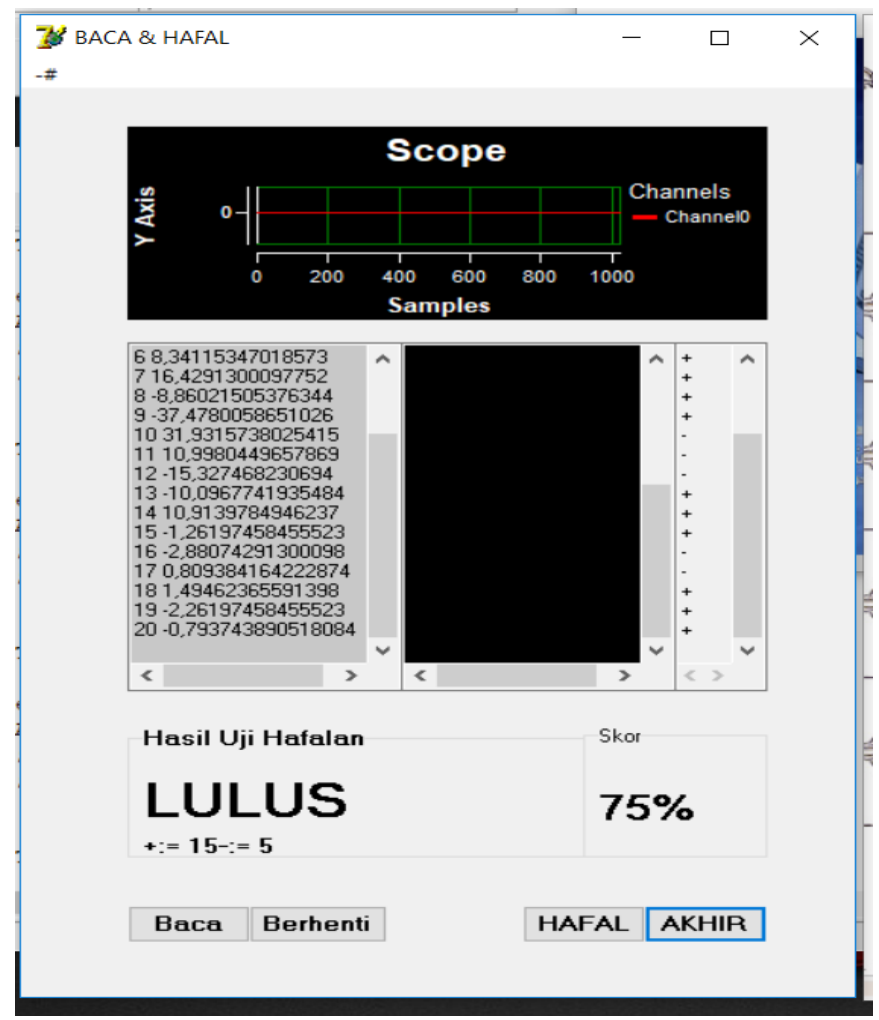

Picture 3.3 The test results after completing the sample voice input in real time

The picture above is the result of the assessment of Ar-Rahman's recitation test system with the results of the "LULUS" memorization test with a score of $75 \%$. This process is an advanced process from the previous image where after the mentor's voice input is finished, input the sample sound directly. The mentor's voice is only included once for the use of a large number of samples, for example 20 votes are sampled in one system usage. 


\section{Conclusion}

The results showed that the design of the Al-Qur'an verse reading and reading system using the Wavelet Transformation algorithm, which was able to help memorize the Surah Ar-Rahman that was popular among the people and with the use of the algorithm, sound image processing in Surah Ar-Rahman could produce better speech recognition.

\section{Bibliography}

Putra, Darma. 2010. Pengolahan Citra Digital. Yogyakarta : Penerbit Andi.

Fadlisyah, dkk. 2013. Pengolahan Suara. Yogyakarta : Graha Ilmu.

Bambang Eka Purnama. 2013. Konsep Dasar Multimedia. Yogyakarta : Penerbit Graha Ilmu.

Deden, M. Makhyaruddin. 2013. Rahasia Nikmatnya Menghafal AlQuran Berdasarkan Pengalaman Penulis Tuntas Menghafal AlQuran dalam 56 Hari. Jakarta : Penerbit Nou 
Implementation of The Wavelet Transformation Algorithm for The Recognition and Recitation of The Qur'anic Verses Through Voice 1 